University of Nebraska - Lincoln

DigitalCommons@University of Nebraska - Lincoln

Faculty Publications, Classics and Religious

Studies Department

January 1969

\title{
The Publication of Apuleius' Apology
}

Thomas Nelson Winter

University of Nebraska-Lincoln, c150gpilot@yahoo.com

Follow this and additional works at: https://digitalcommons.unl.edu/classicsfacpub

Part of the Classics Commons

Winter, Thomas Nelson, "The Publication of Apuleius' Apology" (1969). Faculty Publications, Classics and Religious Studies Department. 28.

https://digitalcommons.unl.edu/classicsfacpub/28

This Article is brought to you for free and open access by the Classics and Religious Studies at DigitalCommons@University of Nebraska - Lincoln. It has been accepted for inclusion in Faculty Publications, Classics and Religious Studies Department by an authorized administrator of DigitalCommons@University of Nebraska - Lincoln. 


\section{THE PUBLICATION OF APULEIUS' APOLOGY}

THOMAS NELSON WINTER

University of Hawaii

How did the text of Apuleius' Apology originate? The question has seldom drawn the attention of scholars. Those who have dealt with it simply assume that Apuleius worked out and elaborated upon whatever he had actually said in court and then had the finished version published. Paul Vallette thus assumes Apuleius must have reworked the speech. ${ }^{\mathrm{I}} \quad$ Adam Abt is so confident that the Apology was improved and augmented that he attempts to determine which sections would have been added for publication. ${ }^{2}$ Georg Misch writes: "He brilliantly defended himself... and he then published a long and lively version of his speech." 3 The purpose of this article is to offer an alternative to this somewhat blithe assumption. There is external evidence, partly from other sources and partly from Apuleius himself, to indicate that the speech could have been recorded and published by stenographers.

The Apology is a long speech. From my own experiments, I find it must have taken almost four hours to deliver. Yet the length of the Apology cannot be used to argue that it must be an extended version of the spoken oration. The defendant was allowed one third more time than the plaintiff had used, ${ }^{4}$ and Pliny boasts of speaking almost five hours, despite poor health, when prosecuting Marius Crispus (Ep. 2.II). Pliny elsewhere records his pleasure at drawing a good crowd at a trial, and keeping the audience spellbound through seven hours (Ep. 4.I6). It is not unlikely, then, that Apuleius did hold forth

'Apulée: Apologie, Florides (Paris 1924 and 1960) xxiv.

2 Die Apologie des Apuleius von Madaura und die antike Zauberei (Giessen 1908) 6-8.

${ }^{3}$ A History of Autobiography in Antiquity, trsl. E. W. Dickes and G. Misch (London 1950) 509.

4 H. E. Butler and A. S. Owen, Apulei Apologia (Oxford 1914) 72. 
almost four hours when defending himself. But could stenographers have kept up with him through a speech of that length?

Probably yes. Practical use of shorthand for the recording of spoken Latin is known from 63 B.C. to the ninth century. ${ }^{5}$ The technique is known from extant shorthand copies and was once revived for experimental purposes. Louis Prosper Guénin, stenographer to the French Senate, discovered, after experimenting with various stylus points, that stenography with stylus and wax tablet was indeed practicable. After some practice, he found himself able to record orations five hours nonstop on wax tablets. ${ }^{6}$ This is consistent with ancient notices of stenography. Eunapius, for instance, speaks of $\tau o \dot{s} \tau \tau \alpha \chi^{\epsilon} \omega s$

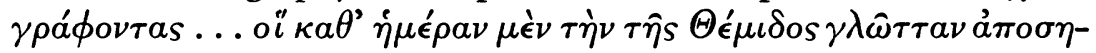

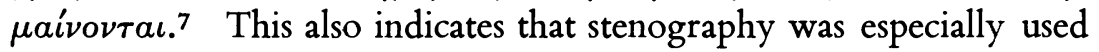
for juridical speeches.

The word used to express "record by shorthand" is excipio. Cicero seems the first to use the verb in this sense, ${ }^{8}$ and, perhaps because it is a neologism, is careful to make his meaning clear: "tum illum [Tages] plura locutum multis audientibus qui omnia verba eius exceperint litterisque mandaverint" (De div. 50). Cicero also provides us with the first speech known to have been stenographed at delivery and published by the stenographer. This is the Pro Milone. Asconius Pedianus reports that there were two speeches: the one Cicero delivered and the one Cicero published.9 How did he know? The former was excepta, and was still extant in Asconius' time. Asconius chooses to study the better version, not because he feels the oratio excepta was unfaithfully recorded (indeed, he mentions no such possibility), but because he feels the longer version is more worth study. He seems to accept the oratio excepta as what Cicero actually said at the trial:

Cicero cum incipit dicere, exceptus est acclamatione Clodianorum, qui se continere ne metu quidem circumstantium militum potuerunt. itaque

5 Weinberger in $R E$, s.v. "Kurzschrift."

${ }^{6}$ L. P. and Eugène Guénin, Histoire de la sténographie (Paris 1908) 233-34.

7 Vit. Soph., "Prohaeresius" 4.1 3.

8 ThLL s.v. "excipio," col. 1253.

${ }^{9}$ Pp. 4I-42 in A. C. Clark's OCT edition of Asconius; p. 36 in the edition of A. Kiessling and R. Schoell. The passage is cited immediately below. 
non ea qua solitus erat constantia dixit. manet autem illa quoque excepta ${ }^{\mathrm{IO}}$ eius oratio; scripsit vero hanc quam legimus ita perfecte ut iure prima haberi possit.

From this famous beginning, stenography seems to have enjoyed wide use in the "catching" of spoken orations, and the stenography of the speeches seems to have had some effect. As J. N. Settle notes concerning the Pro Milone, "This dual existence of a published oration is without parallel." II Thus the first speech known to have been excepta is also the last speech known to have been improved in a subsequent edition by the orator. Perhaps Cicero's successors wished to avoid mockery. Milo, angered by the disparity between the two versions, deliberately set out to make a laughing-stock of Cicero after Cicero had sent him, now exiled, a copy of the improved version. On reading it, Milo opined he was lucky that Cicero had given no such speech, for he would not then be enjoying the fine mullets of Marseilles. "This he wrote, not because he was pleased with his condition-indeed, he made many efforts to secure his return-but as a joke on Cicero, because the orator, after saying nothing useful at the time ... had later composed and sent to him these fruitless words, as if they could then be of any service to him" (Cass. Dio 40.54, trsl. Ernest Cary). Quintilian may reflect how Cicero's experiences with stenography affected later orators. Even though Quintilian was displeased that his orations had been published by stenographers, he did not rewrite them (see below).

Various of Caesar's speeches in the courts might have been published by stenographers. Augustus wondered if the state of Caesar's Pro Q. Metello was the result of publication by a bad stenographer: "Pro Q. Metello non immerito Augustus existimat magis ab actuariis exceptam male subsequentibus verba dicentis, quam ab ipso editam" (Suet. Iul. 55.3). Even this is an indication that the craft was capable of recording a forensic speech with fidelity: if all stenographers' publications were

${ }^{10}$ Even if excepta merely repeats the sense of exceptus in the first line, this cannot change the usual interpretation of the whole. Asconius is speaking of two distinctly different speeches: one which Cicero spoke without his usual constantia, and a second speech, "this one which we are reading," which Cicero scripsit . . ita perfecte. If the spoken version was extant in Asconius' time, it could only have been because a stenographer had recorded it on the spot and then published it.

II "The Trial of Milo and the Other Pro Milone," TAPA 94 (1963) 275. 
unfaithful versions, the words "male subsequentibus" would have been superfluous.

In the Augustan age, the poet Manilius was able to describe the stenographer in these terms (4.197-99):

hinc et erit scriptor velox cui littera verbum est, quique notis linguam superet cursimque loquentis excipiat longas nova per compendia voces.

Throughout the early Empire, stenography was praised by some and taken for granted by others. Seneca, for instance, lists exceptio among the marvels which reason (scire) has wrought: "Quid verborum notas quibus quamvis citata excipitur oratio et celeritatem linguae manus sequatur?" (Ep. 90.25). Even more significant than this praise is the fact that two first-century critics, Asconius and Quintilian, had so much faith in the ability of shorthand that they accepted "the other Pro Milone" as a record of what Cicero had actually said. Quintilian speaks of "oratione pulcherrima, quam pro Milone scriptam reliquit" (Inst. 4.2.25). But later he has occasion to speak of a distinctly different Pro Milone: "unde Ciceroni quoque in prooemio, cum diceret pro Milone, digredi fuit necesse, ut ipsa oratiuncula qua usus est patet" (Inst. 4.2.17). If Quintilian believes he possesses the ipsa oratiuncula qua usus est, it could only be because he believes that some stenographer faithfully recorded the words of Cicero as he was speaking in Milo's behalf. ${ }^{22}$ This at least indicates that stenography in Quintilian's day was both commonplace and capable. He elsewhere complains that all but one of his own speeches in the courts have been published by stenographers (Inst. 7.2.24):

Cuius actionem [that for Naevius of Arpinum] et quidem solam in hoc tempus emiseram, quod ipsum me fecisse ductum iuvenale cupiditate gloriae fateor. Nam ceterae, quae sub nomine meo feruntur, neglegentia excipientium in quaestum notariorum corruptae minimam partem mei habent.

12 I do not see how Settle (above, note II) 277, can call it "hardly tenable" that stenography was responsible for the text of Cicero's other Pro Milone, or refer twice to the idea as a modern view. Asconius and Quintilian both imply that they at least believed that Cicero's actual spoken words were recorded, and Asconius was so understood by both Guillaume Budé (I468-1 540) and Robertus Stephanus (I503-1 559). Cf. the 1740 Basil edition of Robertus Stephanus' Thesaurus Latinae Linguae 2.236, col. 2. 
It is conceivable that stenography became a usual part of rhetorical education. Oratory was learned by studying and memorizing orations, and there would have been no faster or cheaper way to obtain models of current excellence. Thus the emperor Titus, who was educated with Nero in the imperial court (Suet. Titus I), was a skilled exceptor: "e pluribus comperi notis quoque excipere velocissime solitum." Suetonius provides this information not because it was unusual for a noble to be an exceptor, but apparently simply because it introduces an anecdote he wishes to tell: "et cum amanuensibus suis per ludum iocumque certantem" (Titus 3).

Thus the ancient notices of stenography which antedate the Apology of Apuleius indicate that speeches could be faithfully recorded, and that court speeches were especially liable to recording and publication by stenographers. This external evidence alone would oblige us to admit the possibility that Apuleius' Apology was transcribed at delivery. The evidence which the orator himself provides turns possibility to probability.

Throughout all we know of his life, Apuleius was famous enough as an orator to attract exceptores, whether their motive was profit or self-improvement. At some unknown date he remarks that he is obliged to give a speech in just about every town he visits. ${ }^{13}$ This was already true three years before the Apology (55.IO-II):

nec hoc ad tempus compono, sed abhinc ferme triennium est, cum primis diebus Oeam veneram publice disserens de Aesculapii maiestate eadem ista prae me tuli et quot sacra nossem percensui. ea disputatio celebratissima est, vulgo legitur, in omnibus manibus versatur.

The speech he refers to was so read and studied that Apuleius can expect several in the audience to be able to recite the part in question: "dicite aliquis, si qui forte meminit, huius loci principium. audisne, Maxime, multos suggerentis?"

13 Flor. I. The town in question here is called "sanctissimam istam civitatem." Though this has been taken to mean Rome, the town is compared to "aliqui lucus aut aliqui locus sanctus in via." His punning remark "quamquam oppido festinem ... et habenda oratio et inhibenda properatio est," is another indication that some village is meant, rather than such a city as Rome. The line references to Apuleius' Apology and Florida are the chapter and sentence numbers of Paul Vallette's text, cited above, note $I$. 
Apuleius describes his experience with stenography in the ninth section of his Florida, a passage whose significance seems to have been overlooked. This fragment answers one of Apuleius' critics, one of the kind "who prefer to despise their betters than to imitate them" (Flor. 9.2). The critic is asked to look around at the huge and splendid assemblage and to consider how difficult it is to satisfy everyone in such a crowd, "especially for me" (9.6). He continues with that famous remark: "quis enim vestrum mihi unum soloecismum ignoverit?" (9.7). The problem which Apuleius faces is indeed challenging: "meum vero unumquodque dictum acriter examinatis, sedulo pensiculatis, ad limam et lineam certam redigitis" (9.7). Apuleius' public, then has the advantage of him in that they may read and examine at their leisure whatever Apuleius says in his public appearances. He explains the root of the problem: "nam quodcumque ad vos protuli, exceptum ilico et lectum est, nec revocare illud nec autem mutare nec emendare mihi inde quicquam licet, quo maior religio dicendi habenda est" (9.13). Apparently it was Apuleius' normal experience that he could edit nothing once it had passed his lips, for by then stenographers had got it down, and could be trusted to see to it that anyone who wanted to could read it.

It may be instructive to point out a contrast between Quintilian and Apuleius with regard to stenography. Quintilian used stenography as an excuse for the state of his published speeches (see above). Apuleius accepted the fidelity of their copies. His solution is not better stenographers, but better speeches: stenography is for him a spur toward a maior religio dicendi. The ninth fragment of the Florida, then, is a strong indication that every speech we possess of the great orator was published not by Apuleius but by enterprising stenographers, and indicates that we probably have in the Apology not some augmented or "improved" version, but the ipsa oratio which Apuleius gave at his trial. 